\title{
Taxation in Niger: Problems and Proposals
}

\author{
ROBIN BARLOW \\ University of Michigan, Ann Arbor \\ and \\ WAYNE SNYDER* \\ Grand Valley State University, Allendale, Michigan
}

\begin{abstract}
Summary. - The tax structure in Niger depends heavily on uranium mining and the rest of the formal sector. The slump in uranium prices has reduced tax revenues to $9 \%$ of GNP, which is not enough to finance an adequate level of public services. In this paper, tax reforms are considered which will raise more revenue while respecting criteria of equity, efficiency, and growth. The reforms mostly involve extending taxation into the informal sector, such as using external indicators of income in the administration of the income tax, and making greater use of taxes on buildings and motor vehicles.
\end{abstract}

\section{INTRODUCTION}

In recent years Niger has suffered from chronic fiscal troubles. The pattern is common to many impoverished countries of Africa: The price of the country's principal export product collapses, reducing the government's revenues; it proves politically difficult to reduce the level of public services and in particular the size of the bureaucracy; the growing fiscal deficit is handled by a series of desperate stopgap measures - delaying payments to government workers and suppliers, borrowing where possible, and appealing to the international donors for assistance. The donors often respond by saying that the fiscal problems should be solved by thoroughgoing reform, which would address not only the growing deficit but also the numerous distortions and inequities caused by the tax system. Hence there is no lack of advice about how to address the fiscal crisis The purpose of this paper is to review the main problems in Niger's tax system, and to add to the unsolicited advice already in plentiful supply.

\section{BACKGROUND}

Niger covers a large area - more than France, Germany, and Poland combined. But the northern half of the country gets virtually no rainfall, and in that region, agricultural possibilities are extremely limited. Almost all of Niger's eight million people live within 100 miles of its southern border. In that narrow belt, traditional farming and herding are the main activities, millet and sorghum are the main subsistence crops, and livestock and cowpeas are the main exports. Far to the north, the uranium mines developed with French, Japanese, and Spanish participation provide an important supplement to the country's traditional sources of income.

As in most African countries, there is a rather sharp division between the so-called formal and informal sectors of the economy. The formal sector makes extensive use of written records; the informal sector does not. This difference is of prime significance for public finance, since many taxes which are dependent on documentation and which can therefore work well in the formal

\footnotetext{
${ }^{*}$ Much of the material used for this paper was ohtained during a research mission which the authors conducted in Niger in 1991. The mission was administered by Development Alternatives Inc., Bethesda, MD. The authors are grateful for the generous-spirited cooperation extended to them in Niamey by the staff of the Ministry of Finance, by respondents in several other public and private institutions, and by Frank Martin of the United States Agency for International Development. For comments on earlier versions of the paper, thanks are extended to Gérard Chambas, Henri Josserand, Charles Steedman, and two anonymous referees. The authors alone, however, are responsible for the views expressed here. Final revision accepted: January 27, 1993 .
} 
sector encounter serious administrative obstacles when applied to the informal sector. Besides traditional farming and herding, the informal sector in Niger includes an abundance of mercantile activities. Some of the merchants run large and complex operations, and much of the extensive trade with Nigeria to the south is under their control. The informal sector also includes a dynamic, small-scale manufacturing component, mostly found in the villages. ${ }^{1}$

The formal sector encompasses the uranium operations, the civil service, the state enterprises (not very numerous, and mostly engaged in the processing of agricultural products), a few foreign enterprises, and some modern-style service businesses established by Nigeriens educated abroad. $^{2}$ Together these activities probably account for little more than a third of the GNP (Joumard, Liedholm and Mead, 1992, p. 23).

After obtaining its independence from France in 1960 , Niger experienced two long-lived authoritarian regimes. Hamani Diori, a leader in the independence struggle, governed until 1974, when he was overthrown by Seyni Kountché in a military coup. Kountché held power until his death from natural causes in 1987. It was during his regime that Niger enjoyed its uranium boom. Not long after his death, pressures for democratic reform obliged his successor Ali Saibou to begin sharing power, and efforts are now under way to create a multi-party electoral system.

The tax system which evolved from the colonial past and from the first 30 years of independence is summarized in Table $1 .^{3}$ There are several salient features of the system.

First, as in virtually all low-income countries, a large fraction of total tax revenues is generated by international trade $-42 \%$ in the case of Niger in 1989.

Second, SOMAIR and COMINAK, the two companies which comprise the uranium sector, furnish a large fraction of total tax receipts, as a result of paying production royalties, a special export tax, a profits tax, and income taxes on their employees' wages. To this list might be added the extra tax revenues generated in other sectors due to the extra economic activity induced by uranium production.

Third, there have been some significant fiscal changes since independence. The arrival of substantial revenues from uranium mining in the 1970s permitted the virtual removal of the head tax and the livestock tax, traditional levies which had constituted significant burdens for the rural population. Some years later, in 1986, two turnover taxes were replaced by a value-added tax. Apart from these changes, most of the system inherited from the French colonial period is still intact. Thus income taxation involves first taxing each source of income (profits, wages, rent, etc.) under a separate "schedular" tax, then taxing the sum of income from all sources under a "general" tax. Some of the French legacies are truly antique. The business license tax (patente), for example, is closely modeled on a levy dating back to the French Revolution.

Fourth, reflecting the high degree of centralization in French administrative tradition, the central government's taxes generate far more revenue than do local taxes. Among the latter, head taxes in the villages and towns are of some importance, and there is also a proliferation of minor taxes on business operations, such as taxes on the occupancy of market stalls and taxes on advertising signs. The central government acts as the collection agency for most of the local taxes. Most of the local expenditures on supplies are also executed in fact by the central government, so local goverment is left with hardly more responsibility than the management of its own bureaucracy.

This tax system will now be evaluated in terms of the following four criteria:

(a) Revenue adequacy. Does the system generate enough revenue to finance an appropriate level of public services?

(b) Efficiency. Does the system promote an efficient allocation of resources?

(c) Equity. Does the system result in a fair distribution of tax burdens among the different economic groups of the population?

(d) Growth. Does the system promote economic growth?

The criterion of revenue adequacy must evidently be applied to the tax system as a whole rather than to its separate parts. In our discussion here, the whole system is assessed according to the adequacy criterion, then the major components of the system are each assessed in turn according to the criteria of efficiency, equity, and growth. We are then in a position to apply those three criteria to the system as a whole, which is done in the concluding section.

\section{REVENUE ADEQUACY}

In 1989 central and local government tax revenues in Niger amounted to $9 \%$ of GNP. This "tax ratio" is very low by international standards. A compilation published by the International Monetary Fund (1986, p. 84) indicates that in 1982 the mean ratio for developing countries was $19.7 \%$, while that for industrial countries was $34.3 \%$.

The fact that Niger's ratio is far below interna- 
Table 1. Tax revenues in Niger, 1989 (in billions of CFA francs) ${ }^{*}$

\begin{tabular}{|c|c|c|}
\hline \multicolumn{2}{|l|}{ Income taxes } & 14.3 \\
\hline General income tax (IGR) & 4.1 & \\
\hline \multicolumn{3}{|l|}{ Schedular income taxes } \\
\hline Industrial and commercial profits (BIC) & 5.6 & \\
\hline Wages and salaries (ICTS) & 3.0 & \\
\hline Income from financial investments (IRVM) & 1.0 & \\
\hline Rental income (TVL) & 0.6 & \\
\hline \multicolumn{2}{|l|}{ Taxes on internal trade } & 12.5 \\
\hline Valuc-added tax (TVA) & 5.8 & \\
\hline Uranium royalties & 4.9 & \\
\hline Property transfer tax & 0.9 & \\
\hline Tax on insurance contracts & 0.4 & \\
\hline Stamp duties & 0.5 & \\
\hline \multirow{2}{*}{\multicolumn{2}{|c|}{$\begin{array}{l}\text { Taxes on international trade } \\
\text { Imports }\end{array}$}} & 24.0 \\
\hline & & \\
\hline Value-added tax (TVA) & 6.9 & \\
\hline Fiscal duties (DF) & 4.4 & \\
\hline Customs duties (DD) & 1.8 & \\
\hline Statistical tax (TS) & 2.1 & \\
\hline Tax on petroleum products (TPP) & 2.4 & \\
\hline Tax on alcoholic beverages (TBA) & 0.7 & \\
\hline Tax on tobacco products (TSB) & 0.3 & \\
\hline Regional cooperation tax (TCR) & 0.6 & \\
\hline Other import taxes & 0.1 & \\
\hline \multicolumn{3}{|l|}{ Exports } \\
\hline Uranium export tax (DSU) & 2.4 & \\
\hline Statistical tax & 2.3 & \\
\hline \multicolumn{2}{|l|}{ Property taxes and license taxes } & 1.5 \\
\hline Buildings tax $(\mathrm{FB})$ & 0.6 & \\
\hline Business license tax & 0.7 & \\
\hline Motor vehicle license tax & 0.2 & \\
\hline \multicolumn{2}{|l|}{ Local government taxes } & 4.1 \\
\hline \multicolumn{2}{|l|}{ Other taxes } & 0.6 \\
\hline \multicolumn{2}{|l|}{ Total tax revenues } & 57.0 \\
\hline
\end{tabular}

Source: Ministère du Plan (1990).

${ }^{*}$ French acronyms for the taxes are shown in parentheses. The CFA franc is tied to the French franc in a 50:1 ratio. In 1989 the exchange rate between the CFA franc and the US dollar averaged 319:1.

tional norms does not by itself imply that the country has an inappropriately small public sector. It could be that the norms represent excessively large public sectors in the other countries, or that special conditions in Niger make a small public sector appropriate. Given Niger's desire to raise its present level of development, however, it seems self-evident that the country ought to allocate more than $9 \%$ of its total income to certain critical activities which are unlikely to be forthcoming in quantity from the private sector - activities such as the creation of human capital through education and health services; the creation and maintenance of physical infrastructure in such sectors as transportation, communications, irrigation, electricity supply, sanitation, and household water supply; and the provision of internal and external security. Hence the tax system in Niger cannot reasonably be said to generate an adequate level of revenue.

A few years ago, the level of tax revenue was closer to being adequate. In 1980 central govern- 
ment tax revenue, which has typically accounted for well over nine-tenths of total tax revenue, amounted to $12.4 \%$ of GNP. This was the height of Niger's uranium boom, when the export price reached levels not seen before or since. We have noted from Table 1 the central role of the uranium sector in the tax system. The same point is made in Figures 1 and 2 . There is clearly a close correlation between the curve for mining output as a percentage of product (Figure 1) and the curve for "actual total taxes" as a percentage of product (Figure 2). The least-squares regression relationship between the two variables during 1970-89 is as follows:

$$
T A X / G N P=5.23+0.555 M I N / G N P\left[\mathrm{R}^{2}=0.92\right]
$$

$T A X / G N P$ is central government tax revenue as a percentage of GNP, and $M I N / G N P$ is value added in modern-sector mining as a percentage of GNP. ${ }^{4}$ The high $\mathrm{R}^{2}$ means that virtually all of the fluctuations in the tax ratio are explained by the varying fortunes of the uranium sector. The

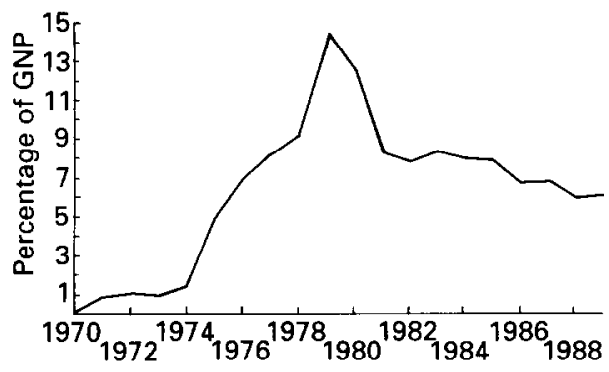

Figure 1. Mining output as a percentage of GNP.

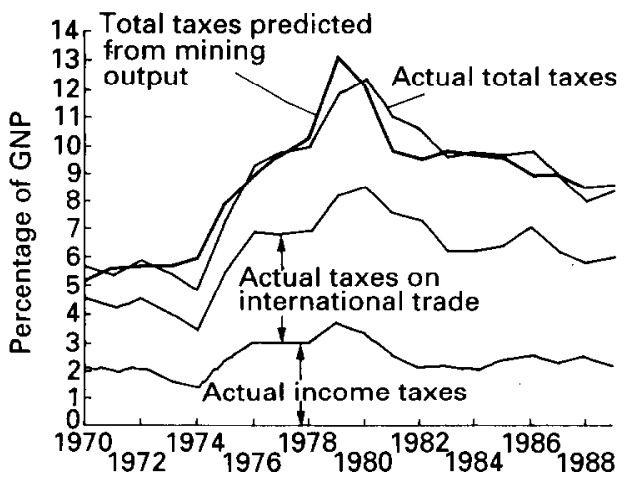

Data are for central government revenue only. Sources: World Bank, World Tables; Ministère du Plan, Annuaire Statistique.

Figure 2. Tax revenue as a percentage of GNP. point is clearly depicted when we add to Figure 2 the bold curve for $T A X / G N P$ as predicted by the regression equation. The correspondence between that bold curve and the light curve for actual $T A X / G N P$ is very close.

Further, it is clear from Figure 2 that the uranium sector has a dominant influence on all of the three broad categories of tax revenue shown there: the income taxes (including the profits taxes and wages taxes paid by the uranium companies), the taxes on international trade (including the uranium export tax), and other taxes (including the uranium royalties).

Briefly put, the fiscal experience of Niger since 1980 has been an attempt to maintain public expenditures at their boom levels in the face of an inexorably shrinking tax ratio. Expenditures from the general budget stayed close to $14 \%$ of GNP throughout the 1980s (Ministère du Plan, 1991). But revenues could not keep pace. The tax structure was rigidly tied to uranium mining and the rest of the formal sector, and the decline in uranium entailed a decline in tax revenue. The government's attempts to resist this process by raising tax rates, bringing in the value-added tax, and strengthening enforcement were all futile. These measures simply stimulated evasion and a transfer of operations out of the formal sector la fuite vers l'informel, as it is commonly called in Niger.

The growing gap between politically necessary expenditures and shrinking receipts was covered by a variety of emergency solutions. One step which governments often resort to in these circumstances - printing enough money to cover the deficit - is not available to Niger, which as a member of the franc zone has only limited discretionary powers of monetary expansion. But other stopgaps were found. There was increasing resort to outside borrowing, and the central government's external debt more than doubled during 1984-88. The international donors were approached for grants, and France in particular, as the former colonial power, could often be counted on to respond. ${ }^{5}$ Treasury officials appealed to local enterprises to pay their taxes early, and some of them, particularly those run by foreigners, considered it politic to comply. Bills submitted by local suppliers to the government were left unpaid, and starting around 1990 , there were substantial delays in the payment of government salaries. Some of the government workers accepted their fate philosophically, talking of their "60-day months" (Martineau, 1992). Others were less passive, and the armed forces reacted on occasion with mutiny. ${ }^{6}$ The management of the budget deficit in Niger has become an exciting affair. 
In both national and international circles, there is agreement that Niger's budgctary deficit ought to be reduced, but there are differences on how that should be achieved. The donors and in particular the International Monetary Fund put considerable emphasis on expenditure reduction (though they also have some ideas on tax reform). The Nigerien view, as expressed for example by Prime Minister Amadou Cheiffou in 1992, is that public expenditure is already at a bare-bones level: he cited a current ratio of one government employee in Niger for every 215 inhabitants, which can hardly be regarded as excessive. ${ }^{7}$ This view - that developmentrelated public services in Niger are already at minimal levels - implies that deficit reduction ought to be accomplished primarily by raising the tax ratio. The current ratio of $9 \%$, as we argued above, is clearly inadequate. But the lesson of the last 10 years, as dramatically depicted in Figures 1 and 2, is that the existing tax structure does not permit a significant rise in the tax ratio so long as the uranium market remains depressed. Fundamental changes in the structure are required.

It should be stressed that our argument in favor of an increase in Niger's tax ratio is intended to permit the financing of essential services without excessive deficits. Some reduction in government expenditure is no doubt justifiable, since cases of overstaffing and unwarranted subsidies are as prevalent in Niger as elsewhere, but a reduction back to the vicinity of $9 \%$ of GNP would seriously handicap the country's development efforts.

We now turn to the specific taxes in the Nigerien system, to see what structural changes might permit a quantum increase in the overall tax ratio, while respecting the additional criteria of equity, efficiency, and growth.

\section{INCOME TAXES}

The system of income taxation in Niger is by its nature horizontally inequitable, in the sense that persons with the same total income pay radically different amounts in tax, depending on the form in which that income is received. Four types of income - profits, wages, rent, and income from financial investments - are taxed at different flat rates under the "schedular" income taxes, and their sum is then taxed at graduated rates under the general income tax. ${ }^{8}$ Dividend income is the hardest hit, since the company profits out of which the dividends are paid are taxed by the profits tax at $45 \%$, the dividends themselves are then taxed at $20 \%$ by the tax on income from financial investments, and the same dividends are then taxed once more under the general income tax at rates which can reach as high as $60 \% .{ }^{9}$

Abolishing the schedular taxes would tend to improve the systcm's "horizontal" equity. A reform of this nature should also be conducive to growth, since the schedular taxes are mostly applied to capital income. Their removal would raise the after-tax rate of return on saving, and should therefore stimulate private saving and investment.

There is, however, a case for retaining some of the schedular taxes as withholding devices. The case certainly applies to the schedular tax on profits, which could be converted into a system for withholding the taxes payable on profit income under the general income tax. This could be achieved through a plan for "full integration" of corporate and individual income taxes as discussed in the public finance literature. ${ }^{10}$ Under such a plan, individuals receiving profit income include in their income subject to general income tax their share of company profits before the application of the profits tax; they then calculate the general income tax due on their total income, and deduct from this provisional tax liability the profits tax already paid on their share of profits. The net result is to avoid the double taxation arising from taxing profits first at the corporate level and then again without adjustment at the individual level.

The multiple taxation of profits is, of course, not unique to Niger. Most countries with profits taxes fail to correct the problem. But with full integration of the kind suggested here, the profits tax in Niger would only impose burdens on foreign owners and on Nigerien residents omitting to file general income tax returns. In a similar spirit, it may be desirable to retain the schedular income tax on wages and salaries as a withholding device, it being understood that the taxes withheld would be fully credited against the general income tax.

With the removal of the schedular taxes, except as withholding devices, the general income tax would remain as the main tax instrument for achieving "vertical" equity - that is, the desired degree of tax progressivity or income redistribution. In principle, the structural features of the income tax - the widths of the tax brackets, the rates applying in the different brackets, the exemptions and deductions could be adjusted to help achieve whatever distributional goals were adopted.

Next, we note that the existing income tax system is almost wholly limited to the formal sector. In a country with eight million people, the profits tax in 1991 was paid by about 200 
companies, the schedular tax on wages was paid by about 2,000 individuals, and there were about 30,000 general income tax returns. The limited coverage of the income taxes is partly due to the rather high exemptions permitted under the general income tax and the wages tax. But it is also due to widespread evasion. Where written records are incomplete or nonexistent, as in the informal sector, the information required for levying the income taxes is not available. The tax authorities have tried to solve this problem, at least in the case of the profits tax, by requiring informal-sector businesses to pay an imputed tax (impôt forfaitaire). This is supposed to be based on profits estimated from external indicators like the size of the premises occupied and the nature of the business. But the process of estimation has not been clearly codified. The imputed taxes end up being matters of negotiation between taxpayer and tax collector, and contribute only trivial sums to the Treasury.

The fact that the income taxes are essentially confined to the formal sector causes problems for revenue adequacy, equity, and efficiency. Much revenue is lost by the failure to reach the many substantial incomes generated in the informal sector. Equity is flouted, since formal-sector incomes are taxed much more heavily than are informal-sector incomes of the same size. The tax system discourages businesses from adopting modern methods and thereby becoming more visible, so efficiency suffers.

One solution to these problems which deserves serious study is to restructure the existing general income tax so that it can be readily applied to the informal sector. This might be done by further development of the forfaitaire principle just referred to. In the case of the general income tax, this means that the tax authorities would supplement the declarations of taxpayers with imputations of their income based on certain external indicators. For this approach to work, the indicators would have to be closely correlated with income and readily observable in both the formal and the informal sectors. Examples are four types of household assets: houses, cars, telephones, and electricity connections. Affluent informal-sector operators possess all of them, and all of them are already registered with the authorities.

The official records of these assets include various details - the construction material used in housing, the floor space, the location of the house, the make of car - which would permit further refinements in imputing income. It would be important in this regard to base the imputation of income and hence the calculation of tax liability on the possession of assets rather than on the consumption of products (e.g., the number of kilowatts consumed, or the number of telephone calls made). Otherwise there would be a stronger tendency for the imputed income tax to distort expenditure patterns, as households attempt to minimize their taxes. For similar reasons, it would be important to base the imputation of income on assets which do not have close substitutes.

The rate structure of the general income tax also needs some attention. There are now eight brackets of taxable income, with the marginal rates of taxation ranging from $2 \%$ up to $60 \%$. It can be argued that the lowest rates are too low, and the highest rates too high. The revenue yielded by the lowest rates hardly justifies the considerable collection and compliance costs for those households - relatively numerous - who are taxed only at those rates. The top rates simply encourage evasion, with deleterious effects on revenue adequacy, economic efficiency, and equity.

A better rate schedule might contain only three brackets, with marginal rates of $10 \%, 20 \%$, and $30 \%$. As already noted, the widths of the brackets (and the level of exempted income) should correspond to vertical equity goals, and should also be set to help achieve whatever revenue target is desired.

\section{TAXES ON INTERNAL TRADE}

In terms of revenue yield, the main taxes on internal trade are the uranium production royalty and the value-added tax. The uranium royalty presents no problems of collection, since there are only two companies which are liable for it. Whether the present rate of the royalty is optimal is another matter. One can accept as a reasonable fiscal goal that the government of Niger should maximize its extraction of the economic rent generated by the uranium deposits. The government's actual share of the rent is essentially determined through negotiation with the French government and the other foreign investors participating in production. The negotiations cover not only what rate of royalty will be levied but also other tax liabilities (e.g., the uranium export tax), what price will be paid by French importers (the main purchasers of the product, at a price often well above the world price), how much ore will be mined, who will be employed in the work force, who will pay for the maintenance of the long public road leading to the mines, and so forth. We attempt no analysis here of that multidimensional game.

By contrast, the value-added tax poses major 
problems of collection. The tax is of the credit variety, widely adopted in Europe and elsewhere over the last 30 years. Under this arrangement, the enterprise collects taxes calculated on its gross sales, and then transfers to the Treasury those collections minus a credit for the taxes charged on its own purchases, as confirmed by invoices. For proper enforcement, the arrangement obviously requires high standards of record-keeping. In Niger the tax authorities have found about 800 enterprises with records adequate for value-added taxation. Enterprises with inadequate records are supposed to be taxed on an imputed or forfaitaire basis similar to that used for the profits tax. Another 4,000 enterprises are reached in this way. But as with the profits tax, the imputed payments are negligible.

The value-added tax is widely resented by the business community in Niger. The rates of taxation which were applied when the tax was introduced in 1986 aroused vigorous protest, and the authorities soon felt obliged to reduce the standard rate from $25 \%$ to $17 \% .{ }^{11}$ Five years later, the merchants in one large market in Niamey were still refusing to collect the tax, and the government had chosen not to force the issue. Cooperation with the tax authorities in Niamey may be less than ideal, but matters in the rest of the country are even worse. In a recent survey of small enterprises, Joumard, Liedholm and Mead (1992), found that $23.3 \%$ of the sampled enterprises located in Niamey were paying the value-added tax, but the figure for the rest of the country was only $1.3 \%$.

The administration of the tax seems to be degenerating, since year by year its total receipts keep declining, at a rate faster than can be explained by the uranium slump. Arrears in the payment of the tax are widespread and chronic. The poor performance of the tax can be captured in one statistic: in 1989 its revenues equaled $2 \%$ of GNP. If the value-added tax were universally levied at a standard rate of $17 \%$, it ought to yield revenues in the neighbourhood of $17 \%$ of GNP. Some of the discrepancy here is due to the fact that much of the GNP is nonmarketed, but on top of that, there is extensive evasion.

The value-added tax does not seem to be making many positive contributions to Niger's fiscal system. Its shrinking yield weakens the system's ability to generate adequate revenues. Since it is overwhelmingly a formal-sector tax, it creates additional inducements for resources to shift into the informal sector, with many resulting inefficiencies. Since it is applied in a haphazard manner, it is impossible to judge whether its impact on the distribution of real income is equitable.
In a high-income setting, the value-added tax has a number of advantages, particularly when judged by the criteria of efficiency and growth. But its adoption in Niger seems to be an example of a transfer of inappropriate technology. Should the tax be abolished? Considerations of realpolitik suggest that abolition is unlikely. The tax was adopted at the strong urging of the French government and the International Monetary Fund, who have also promoted it in many other countries. ${ }^{12}$ Their views on the tax have not changed, and their views still carry some weight in Niamey. It may, however, be possible to rehabilitate the tax to a degree. The tax rate is still so high as to cause substantial evasion. Reducing the rate yet again may slow la fuite vers l'informel. It is even conceivable that in the case of its value-added tax, Niger is on the negatively sloped portion of a Laffer curve, and that rate reduction might increase the tax yield. Encouraging evidence that the yield could be increased is provided by the turnover taxes which were replaced by the value-added tax. In some years, they generated revenues nearly twice the current yield of the value-added tax.

\section{TAXES ON INTERNATIONAL TRADE}

As is clear from Table 1, the structure of taxes on Niger's international trade has become rather complex. Value-added taxes are applied to imports, and can then be claimed as a credit against the internal value-added taxes collected at later stages in the process of production and distribution. There is also a bundle of other import charges - droit de douane, droit fiscal, droit statistique, taxes spécifiques. Other levies are applied to exports.

The most salient feature of the taxes on international trade is that they are widely evaded. It is difficult to see how it could be otherwise in Niger's geographical situation. The country's frontiers stretch for about 3,500 miles, mostly across desert and savanna, and the smugglers have all the advantages over the small corps of customs officials. The so-called "mobile brigades" which are supposed to intercept smugglers are often not mobile at all. Their vehicles are frequently in disrepair, and their radios do not work. The local population, which depends on smuggling for a livelihood, is sometimes uncooperative, to put it mildly (Thill, Berthier and Bezard, 1990, p. 26).

The advantages enjoyed by the smugglers have been strengthened in recent years by the arrival of the Toyota Land Cruiser in the region. Its speed and durability in the hands of the smug- 
glers leave the officials impuissants, as one of them told us. It is a remarkably versatile vehicle which, as someone has pointed out, was a decisive factor in the civil war in Chad next door, and is now creating an unofficial free trade zone. If the smugglers cannot escape, they can try bribery, which is allegedly common. If that does not work, and the officials press charges, the smugglers often go free anyway, thanks to the intervention of a local political boss (Thill, Berthier and Bezard, 1990, p. 30).

Most of the crossborder trade seems to escape taxation. The products where evasion is especially notorious are the cigarettes imported through Benin, the livestock exported to Nigeria, and the gasoline imported from Nigeria. In the case of gasoline, the combination of a high official price in Niger, a heavily subsidized price in Nigeria, an overvaluation of Niger's CFA franc relative to Nigeria's naira, and high import taxes in Niger has created irresistible incentives for smuggling. By 1991, 22 out of Niger's 82 formal-sector gasoline stations had reportedly shut down for lack of business (Mahamadou, 1991, p.11). Many of the stations remaining open had no other customers besides government employees using the gasoline coupons they had been given for official travel. It is a classic case of la fuite vers l'informel, where the informel in this instance is represented by young entrepreneurs standing along rural roads beside their jerry cans, and waving a funnel at passing motorists. Their price is sometimes as low as one-fourth of the official pump price.

Nonetheless, Niger's customs officials do manage to collect some taxes. In 1989 their collections amounted to nearly $4 \%$ of the country's GNP. In evaluating this part of the tax system, one quickly encounters a well-known dilemma. Unless subsequently refunded, taxes on international trade cause inefficiencies in resource allocation, detracting from the pursuit of comparative advantage. On the other hand, essential public services need to be financed, and in lowincome countries there are not many other tax handles besides international trade. Some compromise must be reached.

In Niger the current compromise may not be the best possible. As in the case of value-added taxation, further reduction in rates - at least for some products - could lead to an increase in tax yield, besides improving resource allocation. The customs authorities themselves are skeptical on this point. They note that a recent major reduction in import tax rates was followed by a major reduction in import tax receipts. The tax cut, however, took place in a context of declining economic activity, and there may also have been some weakening of the enforcement effort. The entire episode deserves to be more carefully studied.

\section{PROPERTY TAXES AND LICENSE TAXES}

Finally we consider a miscellaneous group of taxes on property values and on licenses. These two categories shade into each other: a motor vehicle license tax, for example, has many of the characteristics of a property tax on vehicles. Certain forms of property taxation have definite potential in low-income countries, and are often recommended by outside observers. ${ }^{13}$ A tax on urban housing has particular appeal. It has a base which is readily identifiable; it provides a means of reaching the informal sector; and it can be structured to achieve equity goals.

In Niger, the Cadastral Service has surveyed all urban housing, but only rented dwellings are taxed. Since 1986, owner-occupied housing has been exempted from the buildings tax. The situation is of clear benefit to the affluent class high-ranking civil servants, other formal-sector notables, and successful operators in the informal sector.

The story is somewhat similar with motor vehicles. Here is another major form of property which is comprehensively registered, used in both the formal and informal sectors, and correlated with income - hence a good candidate for taxation. In Niger the existing tax on motor vehicle licenses reaches only a small part of the taxable capacity represented by motor vehicle ownership. The size of that capacity has been documented by a recent study of Niger's road transportation sector (Mead et al., 1990). The authors estimate persuasively that the bribes paid by drivers at unauthorized but officially tolerated police roadblocks throughout the country amount to no less than 11 billion CFA francs per year. These payments, known whimsically in that part of the world as la taxe sauvage, are equal to about $20 \%$ of total official tax revenues in Niger.

The transporters evidently find it profitable to stay in business, despite having to pay these charges. To improve economic efficiency and increase public revenues, the government should consider getting rid of the roadblocks and increasing the license tax. The rent previously appropriated at the roadblocks could be divided between the transporters and the government, with part of the government's extra revenue to be spent on preventing the roadblocks from reappearing (better supervision, higher salaries for police). 
Most of the other license taxes in Niger have little or no justification for their retention. The business license tax, which dates back to the French Revolution, imposes arbitrary burdens on business operators according to their occupational classification. The survey by Joumard, Liedholm and Mead (1992) found business license tax payments ranging from $1.1 \%$ of annual sales for food retailing firms up to $13.3 \%$ for metalworking firms, a variation defying economic logic. Despite employing a large number of collection agents, by the standards of Niger, the tax provides only about $1 \%$ of total tax revenue. It does have the virtue of reaching the informal sector, but in a manner which discourages cooperation. Evidently its main practical justification is as an instrument of political control: it provides a means whereby the authorities can keep informed about developments in the small-scale commercial and manufacturing sectors. The fiscal analyst cannot sympathize with the technique of using taxes to accomplish such objectives.

Some license taxes at the local level are similarly questionable. In the surveys conducted by Mead et al. (1990), it was found that the village taxes on the occupancy of market stalls were regressive and a significant deterrent to commerce. The same has been said of the municipal taxes on advertising signs. These levies - along with many others throughout Niger's tax system - seem to create economic distortions all out of proportion to the meager amounts of revenue which they generate.

\section{CONCLUSIONS}

To synthesize the discussion of the previous sections, we can ask how the Nigerien tax system as a whole should be rated, using the four criteria proposed at the outset. As regards revenue adequacy, we have argued that the system is deficient. As regards efficiency, the selective nature of the taxes on income and trade distort business decisions about what to produce, what inputs to use, and what scale of operations to attain. In general, the taxes create incentives to operate outside the formal sector. Enterprises are kept small in order to escape notice, new technologies are ignored for similar reasons, formal record-keeping is avoided (or at least concealed) in order that forfaitaire status can be claimed, and so forth.

To assess the equity of the tax system as such, it would be necessary to have available the results of a comprehensive survey of household income, expenditures, and assets. (To assess the equity of the fiscal system as a whole, it would also be necessary to analyze the pattern of benefits from government expenditures. This pattern could well be elitist, but that takes us too far afield.) In the absence of survey information permitting the measurement of tax incidence, some qualitative judgements can nonetheless be made. The tax system does possess some progressive elements: the exemptions permitted under the schedular and general income taxes, the graduated rate schedule of the general income tax, and the higher rates of value-added taxation applied to luxury products. These features are offset to an unknown degree by the regressive tendencies of a tax structure based largely on consumption. But from an equity standpoint, the system's most obvious feature is perhaps its horizontal inequity. Households at the same economic level are taxed at very different rates, depending on how they receive or spend their income. These disparities are well known, and result in even more strenuous efforts at evasion.

As for growth, there too the picture is mixed. The nontaxation of most investment income generated by the informal sector presumably raises the economy-wide after-tax rate of return on investment, and hence contributes to a higher rate of capital formation. The heavy taxation, however, of investment income generated by the formal sector must have the opposite effect. Further negative effects on growth must come from the tax-induced bias against the adoption of new technology and other forms of modernization.

To solve some of these problems, various suggestions have been made in the preceding sections. In sum, they consist of developing imputational procedures under the general income tax, repealing the schedular income taxes except as tax-withholding devices, lowering the rates of value-added and customs taxation, and increasing property taxes on vehicles and owneroccupied buildings. If these suggestions were implemented, the modified tax system might produce revenue as indicated below, after a fairly short period of adaptation (see Table 2). The estimates in Table 2 assume that the value of uranium output remains at the 1989 level. They also assume the abolition of the distortionary levies on business activities such as the business license tax and the local taxes on market stalls.

Two final points should be made, the first one political. The fiscal plan proposed here involves the bureaucracy imposing heavier taxes on some informal sector incomes. The politics of the plan is therefore not without complications, since the ethnic group which has controlled the bureaucracy since independence is not the same as the 
Table 2. Tax revenue as a percentage of GNP under proposed plan

1. General income tax, applying to actual and imputed 3.0 incomes and integrated with profits tax

2. Profits tax

3. Uranium royalties and uranium export tax international trade, at lower rates

5. Property taxes on buildings and motor vehicles 3,0

6. Other taxes 1.5 Total 1.50

ethnic group which dominates the informal sector. ${ }^{14}$ Heavier taxation of the informal sector is probably only feasible if that sector participates fully in political decision making. Hence the democratization now under way in Niger might well be a precondition for successful tax reform. This last point is reinforced when one considers that democratization is likely to lead to a strengthening of local governments, and to the development of their own tax bases. This process could ease the fiscal difficulties of the central government.

The second point concerns the technology of tax collection. Advances in computer technology have created many new possibilities for tax enforcement. For a country such as Niger, the establishment of a national tax registry seems well within present administrative capahilities Such a registry would bring together for each taxpayer all information relevant for determining tax liability: formal-sector wages and investment income, house type and value, motor vehicle data, telephone and electricity connections, and so forth. In the case of Niger the total number of separate taxpaying units under the plan proposed here would not exceed 50,000 (excluding bordercrossers paying customs taxes). Hence the $\operatorname{tax}$ registry might even be managed on a single largecapacity microcomputer. Of course, in this area too, democratic reform might be a precondition for success. Otherwise the tax registry would probably be viewed as yet another instrument of political control.

\section{NOTES}

1. For a detailed analysis of small-scale informalsector enterprises in Niger, see Mead et al. (1990).

2. For a detailed analysis of the private sector in Niger, including both formal-sector and informal-sector enterprises, see Courcelle and de Lattre (1988).

3. For more detailed descriptions of the system, see Barlow and Snyder (1991), Chambas (1991), and the International Bureau of Fiscal Documentation (various years).

4. The number in parentheses is the standard error of the coefficient. Chambas (1991) obtains a closely similar regression result, using some slightly different data series and a slightly shorter period of analysis. The coefficient of 0.555 on the mining output variable implies that an extra 100 million francs of mining output generates additional taxes of 55.5 million francs, both directly and indirectly. In view of the multiplicity of taxes paid by the uranium sector and the importance of the sector's indirect contribution to tax revenues, the coefficient's value is quite plausible.

5. Some of the requests for funds passed through indirect channels. Kpatinde (1992, p. 24) tells of the
Nigerien leaders asking President Houphouet-Boigny of the Côte d'Ivoire to make a special appeal on their behalf to President Mitterand. The French government responded with a geste of three billion CFA francs (about $\$ 10$ million).

6. One of the mutinies occurred in connection with Niger's participation in Operation Desert Storm in 1991. An army contingent was sent to join the coalition forces in Saudi Arabia. The government of Kuwait sent money to Niamey to be paid to the soldiers on their return. When the soldiers returned, they were told the money had already been spent. They refused to turn in their weapons, but were eventually paid.

7. See Martineau (1992). To reinforce the point, one could note that about 37 of those 215 inhabitants are chldren aged $6-11$, who ought to be in school and occupying the attention of at least one teacher.

8. Formally speaking, the tax on rental income (taxe sur la valeur locative) is not counted as a schedular income tax, but it effectively belongs in that category.

9. The schedular and general income taxes are partially integrated in the sense that schedular tax 
payments are deductible from income subject to the general tax.

10. See, for example, Stiglitz (1986), pp. 464-467.

11. Three rates are applied by the value-added tax: a rate higher than the standard rate for some luxury commodities, and a rate lower than the standard rate for some necessities.
12. The spread of the value-added tax across the Third World is amply documented by Tait (1988).

13. See, for example, World Bank (1988), pp. 161162.

14. For an extended discussion of these matters, see Charlick (1991).

\section{RFFF.RFNCFS}

Barlow, Robin, and Wayne Snyder, "The Nigerien tax system: Evaluation and reform" (Bethesda, MD: Development Alternatives, Inc., 1991).

Chambas, Gérard, "Ajustement des finances publiques et développement au Niger," in Patrick Guillaumont and Sylviane Guillaumont (Eds.), Ajustementit Structurel, Ajustement Informel: Le Cas du Niger (Paris: Y. Harmettan, 1991).

Charlick, Robert P., Niger: Personal Rule and Survival in the Sahel (Boulder: Westview Press, 1991).

Courcelle, Michelle, and Anne de Lattre, "The private sector in Niger" (Paris: Organization for Economic Cooperation and Development, 1988).

International Bureau of Fiscal Documentation, Supplement (Amsterdam: various years).

International Monetary Fund, International Financial Statistics: Supplement on Government Finance (Washington, DC: IMF, 1986).

Joumard, Isabelle, Carl Liedholm, and Donald Mead, "The impact of laws and regulations on micro and small enterprises in Niger and Swaziland," Technical Papers, No. 77 (Paris: OECD Development Centre, 1992).

Kpatinde, Francis, "Paix des braves à Niamey," Jeune Afrique, No. 1632 (April 16-22, 1992), pp. 24-26.

Mahamadou, Aboubacar, "De plus en plus de clés sous le paillasson," Sahel Dimanche (May 3, 1991), pp. $10-11$.
Martineau, jean-Christophe, "L'emploi avant tout," Jeune Afrique Economie, No. 151 (January 1992), p. 75 .

Mead, Donald C., Thomas Dichter, Yacob Fisseha, and Steven Haggblade, "Prospects for enhancing the pcrformance of micro and small-scale nonfarm enterprises in Niger" (Washington, DC: GEMINI Project, United States Agency for International Development, 1990).

Ministère du Plan, Annuaire Statistique 1989-90 (Niamey: Government Printer, 1991).

Ministère du Plan, Comptes Economiques de la Nation (Niamey: Government Printer, 1990).

Stiglitz, Joseph E., Economics of the Public Sector (New York: Norton, 1986).

Tait, Alan $\Lambda$., Value Added Tax: International Practice and Problems (Washington, DC: International Monetary Fund, 1988).

Thill, Jean, Emmanuel Berthier, and Bruno Bezard, "Rapport de la Mission 'Fiscalité et ajustement structurel au Niger"' (Paris: Inspection Générale des Finances, 1990).

World Bank, World Tables 1992 (Baltimore: Johns Hopkins University Press, 1992).

World Bank, World Development Report 1988 (New York: Oxford University Press, 1988). 